\title{
PENCEGAHAN PERILAKU BULLYING PADA SISWA KELAS VII DI MTS NAHDHATUL WATHAN
}

\author{
Rachmawaty M Noer ${ }^{1}$, Muhammad Rabi ${ }^{2}$, Osi Draini ${ }^{3}$, Sri Wigati ${ }^{4}$ \\ 1,2,3,4) Prodi Profesi Ners, STIKes Awal Bros Batam \\ email: rachmawatymnoer1977@gmail.com
}

\begin{abstract}
Abstrak
Bullying adalah tindakan negatif dan sering agresif/manipulatif atau serangkaian tindakan yang dilakukan oleh satu atau lebih terhadap orang lain selama periode waktu dan didasarkan karena adanya ketidakseimbangan kekuasaan (Nauli Fathra Annis dkk, 2017). Di Indonesia, Kasus Bullying yang tercatat Komisi Perlindungan Anak Indonesia (KPAI) mencatat 24 kasus kekerasan terhadap anak sekolah. Kasus-kasus tersebut tercatat sejak awal Januari hingga 13 Februari 2019. Hasil tersebut bersumber dari Program Asesmen Mahasiswa Internasional (PISA) OECD 2018. Sebanyak 41\% pelajar Indonesia dilaporkan di-bully setidaknya beberapa kali dalam sebulan. Di Indonesia, proporsi siswa yang di-bully adalah 23\% lebih tinggi dari rata-rata OECD. Di saat yang sama, $80 \%$ pelajar Indonesia mengakui bahwa mereka perlu membantu anak-anak yang mengalami perundungan. Walaupun di Kota Batam secara statistik belum didapatkan kasus bullying yang terjadi kasus bullying sering terjadi dikalangan siswa. Hal ini akan berdampak negatif bagi pertumbuhan dan perkembangan siswa. Menyadari pentingnya akan hal tersebut maka tim pengabdian masyarakat STIKes Awal Bros Batam akan memberikan edukasi pencegahan perilaku bullying melalui media audio visual bagi siswa di kelas VII MTS Nahdhatul Wathan Batam.
\end{abstract}

Kata Kunci : Bullying, Pertumbuhan, Dampak

\begin{abstract}
Bullying is negative and often aggressive / manipulative action or acts of action committed by one or more people against another over a period of time and because of an imbalance of power (Nauli Fathra Annis et al, 2017). In Indonesia, the Bullying cases recorded by the Indonesian Child Protection Commission (KPAI) recorded 24 cases of school child violence. Cases were recorded from early January to February 13 2019. These results are sourced from the 2018 OECD International Student Assessment (PISA) Program. 41\% of Indonesian students report being bullied at least several times a month. In Indonesia, the proportion of students being bullied is $23 \%$ higher than the OECD average. At the same time, $80 \%$ of Indonesian students stated that they need to help children who are bullied. Although in Batam City, statistically, there has not been any bullying case that occurred, the bullying case often occurs among students. This will have a negative impact on student growth and development. Realizing the importance of this, the community service team of STIKes Awal Bros Batam will provide education on the prevention of bullying behavior through audio-visual media for students in class VII MTS Nahdhatul Wathan Batam.
\end{abstract}

Keywords: Bullying, Growth, Impact

\section{PENDAHULUAN}

Bullying adalah suatu pengalaman yang biasa di alami oleh sebagian anak anak atau remaja di sekolah (Safaria and Rizal 2019). Perilaku ini dapat berupa ancaman fisik maupun lisan. Beberapa perilaku bullying seperti ancaman, mengejek, mencela ,merampas dan memukul dilakukan individu atau juga kelompok. Bullying juga dapat berupa tindakan tidak langsung seperti menjauhi karena di anggap berbeda (Riadi 2018). Bullying sendiri pada dasarnya tindakan intimidasi ataupun psikologisy yang terjadi berulang - ulang secara terus menerus membentuk suatu pola tindak kekerasan. Bullying pun sendiri berbeda dengan perkelahian yang biasa terjadi pada anak. Korban bully ini biasanya anak yang lebih lemah di banding si pelaku tindak bullying. (Iksanuddin). Saat ini, bullying merupakan istilah yang sudah tidak asing di telinga masyarakat Indonesia. Bullying adalah tindakan penggunaan kekuasaan untuk menyakiti seseorang atau sekelompok orang baik secara verbal, fisik, maupun psikologis sehingga korban merasa tertekan, trauma, dan tak berdaya (Sejiwa, 2008). Pelaku bullying 
sering disebut dengan istilah bully. Seorang bully tidak mengenal gender maupun usia. Bahkan, bullying sudah sering terjadi di sekolah dan dilakukan oleh para remaja. Dampak yang diakibatkan oleh tindakan ini pun sangat luas cakupannya. Remaja yang menjadi korban bullying lebih berisiko mengalami berbagai masalah kesehatan, baik secara fisik maupun mental. Adapun masalah yang lebih mungkin diderita anak-anak yang menjadi korban bullying, antara lain munculnya berbagai masalah mental seperti depresi, kegelisahan dan masalah tidur yang mungkin akan terbawa hingga dewasa, keluhan kesehatan fisik, seperti sakit kepala, sakit perut dan ketegangan otot, rasa tidak aman saat berada di lingkungan sekolah, dan penurunan semangat belajar dan prestasi akademis. (ZAKIYAH, 2017). Perilaku ini kurang mendapat perhatian, bahkan ada pihak-pihak yang tidak menganggapnya sebagai hal yang serius. Padahal menurut beberapa peneliti (dalam Veenstra et al, 2005) bullying menimbulkan ancaman serius terhadap perkembangan yang sehat selama masa sekolah. Pelaku bullying (disebut Bully) berisiko tinggi terlibat dalam kenakalan remaja, kriminalitas dan penyalahgunaan alkohol. Konsekuensi negatif dalam jangka panjang juga terjadi pada korban bullying (disebut Victim) dimana secara umum korban benisiko tinggi mengalami depresi dan harga diri yang rendah saat masa dewasa. Bullying di antara anak-anak dan remaja merupakan masalah penting yang mempengaruhi kesejahteraan dan fungsi psikososial. (Sugiariyanti, 2009). Bullying telah menjadi tradisi yang berkelanjutan, karena remaja mencari jati diri dengan mengintegrasikan diri ke dalam peer group, sehingga menjadikan peer group (dalam hal ini senior) sebagai role model. Remaja rela dianggap sebagai korban karena membutuhkan pengakuan sosial, sehingga mereka hanya menerima semua perlakuan yang diberikan oleh kelompok sebaya. Baik itu ringan, sedang atau berat, setiap sekolah memiliki masalah dengan penindasan pada siswa. Tergantung dari institusi pendidikannya, SD, SMP, SMA / sederajat bahkan pendidikan tinggi juga berbeda. Siswa dapat menjadi pelaku bullying siswa lain, atau menyaksikan kejadian bullying di lingkungan sekolah.

Tanjung riau merupakan sebuah kelurahan yang berada di wilayah kecamatan Sekupang kota Batam. Kelurahan ini berada dibawah wilayah administratif Puskesmas Sekupang. Mata pencarian penduduk di Kelurahan Tanjung Riau mayoritas berprofesi sebagai nelayan, beberapa mata pencarian masyarakat lainnya yaitu pedagang, pegawai negeri dan karayawan swasta. Kelurahan tanjung riau memiliki perbatasan wilayah sebagai berikut, sebelah utara berbatasan dengan Kelurahan Sei Harapan , sebelah selatan berbatasan dengan Kelurahan Tanjung Uncang, sebelah Timur berbatasan dengan Kecamatan Batu Aji, dan disebelah barat berbatasan dengan Kecamatan Belakang Padang.

Sarana kesehatan yang terdapat di Kelurahan Tanjung Riau adalah, Puskesmas Sekupang, Puskesmas Pembantu dan Polindes. Selain ketiga sarana kesehatan tersebut, warga di kelurahan ini memanfaatkan kegiatan posyandu yang diadakan setiap bulannya untuk mendapatkan pelayanan kesehatan. Fasilitas pendidikan cukup banyak di wilayah Kelurahan Tanjung Riau delapan sekolah dasar, dan tiga sekolah menengah pertama. Tentunya dengan banyaknya sekolah di wilayah ini berbarengan dengan jumlah anak usia sekolah yang tinggi mulai dari SD hingga SMP. Anak usia sekolah adalah anak yang berada pada usia usia sekolah dengan usia 7 sampai dengan 15 tahun menurut Permenkes No.4 Tahun 2019. Usia sekolah merupakan tahapan perkembangan anak yang dapat menghadapi dan menyelesaikan tugas atau perbuatan sehingga dapat menghasilkan sesuatu.

Banyaknya jumlah anak usia sekolah disebuah wilayah atau sekolah sangat dikhawatirkan terjadinya kasus bullying yang belakangan marak terjadi dan diberitakan melalui berbagai media cetak, elektronik ataupun media sosial. Menyadari pentingnya penecgahan perilaku bullying di kalangan siswa maka Kami bermaksud untuk mengadakan kegiatan pengabdian masyarakat di MTS Nahdhatul Wathan Kota Batam.

\section{METODE}

Kegiatan pengabdian dilaksanakan di MTS Nahdhatul Wathan Kota Batam dengan dihadir 65 orang siswa. Metode yang digunakan pada kegiatan ini adalah penyuluhan tentang cara pencegahan perilaku bullying dengan menggunakan media audio visual, ceramah dan Tanya jawab. Kegiatan ini dilaksanakan berdasarkan perencanaan yang telah tertuang dalam pre planning yang disusun oleh tim pengabdian masyarakat.

Metode pengumpulan data dilakukan dengan melakukan cara berkoordinasi dengan pemegang program Pelayanan Kesehatan Peduli Remaja (PKPR) Puskesmas Sekupang mengenai jumlah siswa usia sekolah dan jumlah sekolah SMP/Sederajat yang ada dikelurahan Tanjung 
Riau, kemudian Tim melakukan wawancara dengan guru BK/ Waka Kesiswaan dalam ini diwakili oleh WaKa Kurikulum mengenai kasus bullying yang ada di MTS Wahdatul Wathan dan dilakukan penyebaran kuesioner pretest. Kegiatan penyulihan diawali dengan penayangan film tentang bullying dan selanjutnya dilakukan penyuluhan tentang jenis-jenis bullying, pencegahan bullying, dampak bullying baik bagi korban dan pelaku serta penangan bullying di sekolah. kemudian akan diberikan edukasi kesehatan tentang bullying dengan menggunakan audiovisual dan pemberian kusioner post test untuk mengetahui tingkat pemahaman pada siswa-siswi tentang sikap dan perilaku terhadap bullying. Kegiatan diakhiri dengan sesi Tanya jawab dan pemberian reward terhadap sisa siswi yang mampu berperan aktif serta penyerahan kenang - kenangan kepada pihak sekolah.

\section{HASIL DAN PEMBAHASAN}

Pengabdian masyarakat ini dilakukan di MTS Nahdhatul Wathan Kota Batam. Kegiatan dilaksanakan dengan mengunakan metode ceramah dengan media audio visual yang menyangkan film tentang bullying di kalangan siswa. Materi penyuluhan terdiri dari jenis-jenis bullying, pencegahan bullying, dampak bullying baik bagi korban dan pelaku serta penanganan bullying di sekolah. Dalam pelaksanaan kegiatan juga dilakukan pemberian leaflet yang berisikan tentang pencegahan perilaku bullying di kalangan siswa terutama siswa MTS Nahdhatul Wathan Kota Batam. Dari evaluasi melalui post tes yang dilakukan terjadi perubahan pengetahuan siswa tentang pencegahan perilaku bullying.

Dari 65 orang siswa yang hadir saat penyuluhan sebanyak 62 orang (95\%) memiliki pengetahuan yang baik tentang pencegahan perilaku bullying. Hal ini bermakna bahwa siswa MTS Nahdhatul Wathan memahami tentang perilaku pencegahan bullying yang meliputi jenis-jenis bullying, pencegahan bullying, dampak bullying baik bagi korban dan pelaku serta penanganan bullying di sekolah.
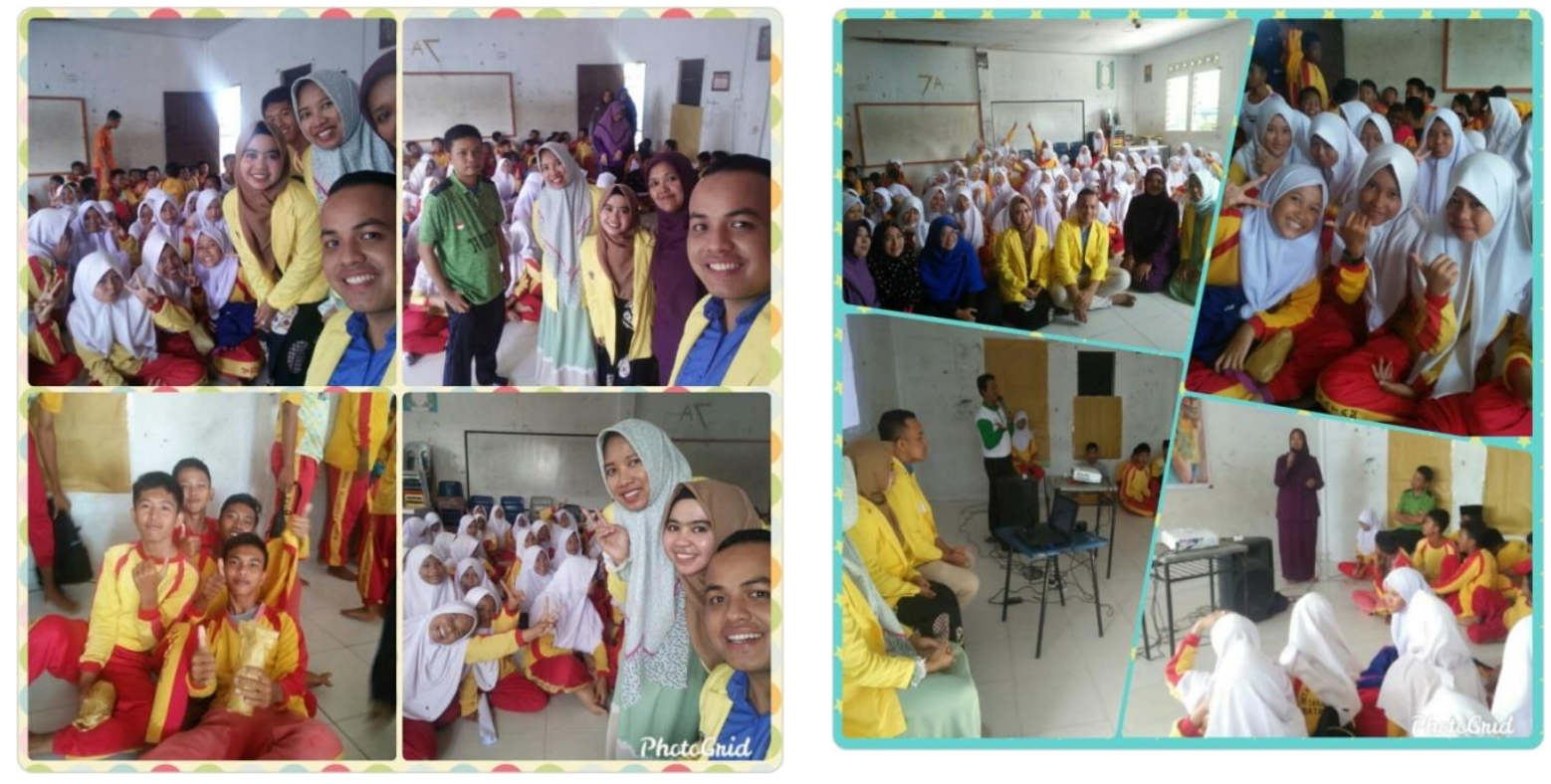

\section{SIMPULAN}

\section{Gambar 1. Kegiatan Sosialisasi Bullying Pada Remaja}

Tehnik penyuluhan dengan menggunakan media audiovisual dan ceramah dapat meningkatkan pengetahuan siswa tentang perilaku pencegahan bullying dengan hasil post tes sebanyak $95 \%$ dengan kategori baik. Dengan demikian diharapakan siswa dapat memahami dampak perilaku bullying dan mengetahui cara penanganannya secara tepat.

\section{UCAPAN TERIMA KASIH}

Ucapan terima kasih penulis sampaikan kepada Kepala Sekolah MTS Nahdhatul Wathan Kota Batam dan seluruh siswa MTS Nahdhatul Wathan Kota Batam yang turut menjadi responden. 


\section{DAFTAR PUSTAKA}

Ahmed, E. \& Braithwaite, V. (2004). Bullying and victimization: Cause forconcern for both families and schools.Social Psychology of Education,7(1) 35-54.ssegaf, A.R. (2004)Pendidikan Tanpa Kekerasan. Tipologi kondisi, Kasus danKonsep. Yogyakarta : Tri WacanaAtes

A.D.danYagmurlu B.(2010)Examining Victimization in Turkish SchoolsEuropan Journal of Educational Studies 2(1)31-37Azwar, S.(2009).Validitas dan Reliabilitas. Yogyakarta: Pustaka pelajar.

Berzonsky, D.M.(2001).Moral Development. Child development. USA: TheMacMillan Psychology Reference Series.

Burns, D.D.(2010).Konsep Diri, Teori Pengukuran Perkembangan dan Perilaku.(penerjemah:Eddy). Jakarta : Arcan.

Calhoun, J.F., and Acocella, J.R.(2004).Psikologi Tentang Penyesuaian danHubungan Kemanusiaan(penerjemahSatmoko)Semarang : Penerbit IKIP Semarang. 